\title{
Distribution of Heavy Metals and Rare Earth Elements in the Surface Sediments of Penang River Estuary, Malaysia
}

\author{
M. C. Ong',2, F. M. Fok ${ }^{1}$, K. Sultan' ${ }^{1}$, B. Joseph ${ }^{3}$ \\ ${ }^{1}$ School of Marine and Environmental Sciences, Universiti Malaysia Terengganu, Kuala Terengganu, Malaysia \\ ${ }^{2}$ Sunda Shelf Research Group, Universiti Malaysia Terengganu, Kuala Terengganu, Malaysia \\ ${ }^{3}$ Institute of Oceanography and Environment, Universiti Malaysia Terengganu, Kuala Terengganu, Malaysia \\ Email: ong@umt.edu.my
}

Received 13 October 2015; accepted 22 January 2016; published 25 January 2016

Copyright (C) 2016 by authors and Scientific Research Publishing Inc.

This work is licensed under the Creative Commons Attribution International License (CC BY). http://creativecommons.org/licenses/by/4.0/

(c) (i) Open Access

\begin{abstract}
Geochemical sediment of the tropical Pinang River, Malaysia was carried out with the aim at documenting elemental concentrations and pollution level assessment. Concentration of selected heavy metals ( $\mathrm{Cu}, \mathrm{Cd}, \mathrm{Cr}, \mathrm{Pb}, \mathrm{Zn}$ and $\mathrm{Mn})$, rare earth elements, TOC and grain size distribution of sediments were determined at $100 \mathrm{~m}$ sampling interval along the river. Sediment size showed a positive correlation with $\Sigma$ REE and $\mathrm{Mn}$ and medium correlations with $\mathrm{TOC}, \mathrm{Zn}, \mathrm{Cu}, \mathrm{Cr}$ and $\mathrm{Pb}$ contents showing enrichment in the clay size fraction. Results of enrichment factor and geoaccumulation index showed that most of the elemental sources were natural (especially REE) and mostly likely represented background values. However, pollution load index revealed the higher levels of $\mathrm{Cr}, \mathrm{Cd}, \mathrm{Zn}$ and $\mathrm{Pb}$, and, therefore, indicating to the anthropogenic sources (i.e. fishing activities) especially in the downstream locations. Thus, the Pinang River is classified as moderately to highly polluted.
\end{abstract}

Keywords

Heavy Metals, REE, Tropical River, Sediment, Pollution, Penang, Malaysia

\section{Introduction}

Heavy metals and rare earths elements (REEs) are potentially toxic inorganic substances in the environment. Persistence and bioaccumulation of such elements may reach a certain threshold of toxicity to aquatic life and therefore, to the food chain systems [1]-[4]. River sediments carry potential of being repository of metals and may serve as a sink first by sorption of metals from the water column [3] and then as a source at elevated levels 
under the varying conditions (e.g. pH, Eh, temperature). Generally, heavy metals and REE are added to the riverine system by natural processes such as rock weathering, volcanic eruption and long distance atmospheric dust [5]. However, in recent times, the major source of metals is related to the human activities including industry, agriculture, urban development and waste discharge [1] [6] [7].

Rare earth elements are being widely exploited due to the ever rising demand in modern gadgetry manufacturing such as magnet, catalyst, alloy, glasses, and related electronics [8]. Particularly at risk are the benthic communities that accumulate the toxic contents in sediments and transfer them to the higher trophic level [3] [9]. Thus, the health of living organisms on higher trophic level of food chain in aquatic and terrestrial ecosystems (e.g. human) will be affected as most protein sources of human are derived from aquatic ecosystems [2] [9] [10]. River and estuarine sediments can be used to assess the pollution level of heavy metals and REEs as the surface sediments interact with water column and record the depositional pollution history [11].

Pinang River is one of the seven most contaminated river basins in Malaysia and is classified as Class-IV by the Interim National Water Quality Standards for Malaysia [12] [13]. Mostly the wastewater discharges do not undergo appropriated water treatment. Land cover and land use change have also enhanced the removal, transport and accumulation of metals in sediments. The shore has been extended outwards through successive land reclamation which has moved the estuary seaward and the resultant changes of saline water intrusion during high tides which may affect the distribution of heavy metals and REE [14]. In tropical settings (marked by high rainfall and temperature), the contaminated river sediments pose even greater risk of becoming the secondary source of pollutants to the ocean as it may re-dissolve back from sediments into water column via remobilization through disturbance of physical, chemical and biological process. This work is important because Penang River provides many services such as drinking water, source of proteins (e.g. fish), transportation, agriculture, electricity generation and tourism. The primary aim of this study is, therefore, to determine the concentration of heavy metals and rare earth elements in surficial sediments of Penang River, and to assess the pollution level by using enrichment factor (EF) and Index of Geoaccumulation $\left(I_{\text {geo }}\right)$.

\section{Material and Methods}

\subsection{Study Area}

Pinang River is located in the northeast of Penang Island, Malaysia, as shown in Figure 1. Pinang River meanders and flows eastward into the sea and is the sub-basin of the larger Pinang River basin (total area $\sim 50.97 \mathrm{~km}^{2}$; length $\sim 3.1 \mathrm{~km}$ ) [15]. Headwaters of Penang River drain hilly granitic rock which is island's bedrock. Middle and lower catchment areas consist of Quaternary deposits (clay, silt, sand, peat and minor gravel). The highest peak is $833 \mathrm{~m}$ ASL located in the north of island. Study area experiences tropical rainforest climate with average annual rainfall of $2670 \mathrm{~mm}$ and average annual air temperature of $27^{\circ} \mathrm{C}$. Transport and deposition of dust particles by wind from perennial but transient forest fires create haze and is a source of atmospheric input of elements.

\subsection{Sampling}

Sampling cruises were made aboard the research vessel that also served as sample processing platform. Surface sediments (0 - $10 \mathrm{~cm}$ depth) were collected with an interval of $100 \mathrm{~m}$ in July 2013 from 24 locations (Figure 1) using Ponar grab that minimized the fine sediments from being washed out by water. The systematic sampling campaign allowed not missing any hotspots that might contain extreme level of potentially toxic metals. Distance between the upstream sampling station and the downstream station was less than $3 \mathrm{~km}$. Sampling locations were recorded using Global Positioning System (GPS) and in-situ data included pH, EC and other parameters (e.g. temperature) using Quanta Hydrolab. The apparatus used were soaked in 10\% of nitric acid overnight and rinsed with distilled water for sampling and laboratory analysis as per QA/QC program (EPA, 1997). Buffer solutions (pH 3, 7 and 10) were used in calibration for Quanta hydrolab.

\subsection{Analytical}

Sediment samples were dried at $60^{\circ} \mathrm{C}$ in a clean oven for one week. Coarse debris and gravel in the sample were removed manually. The dried sediments samples were used to determine the concentration of heavy metals, REEs, TOC and grain size of sediments. For the total digestion about $50 \mathrm{mg}$ of sample was transferred into the 


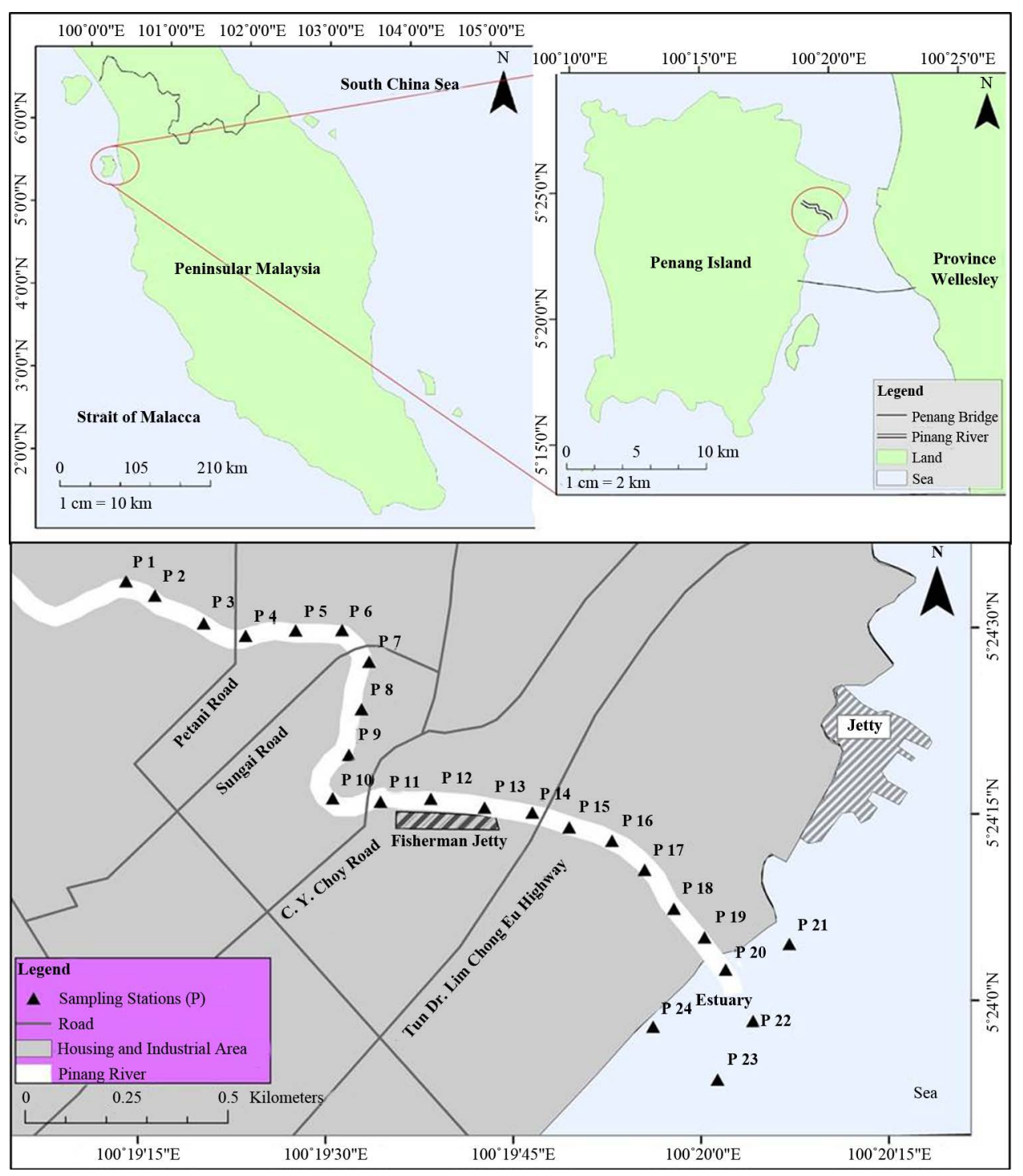

Figure 1. Study area map showing surface sediment sampling stations along the Pinang River, Malaysia.

Teflon cup along with $2 \mathrm{~mL}$ of mixed acids of $\mathrm{HNO}_{3}, \mathrm{HCl}$ and $\mathrm{HF}$ in the ratio of 3:3:1, respectively. The Teflon cup was enclosed in a pressure bomb and heated at $100^{\circ} \mathrm{C}$ for 7 hours until a clear solution without residue obtained. After cooling down, sample was brought to volume of $10 \mathrm{~mL}$ using Milli-Q water $(18.2 \mathrm{M} \Omega \cdot \mathrm{cm})$. Concentration of heavy metals and REE were then measured by the multi-elements technique using Inductively Coupled Plasma Mass Spectrometry (ICP-MS) (Method EPA 6020A; EPA, 2007).

Precautions were taken and appropriate procedures were followed as part of the QA/QC program throughout the analysis. Blank solution was prepared which only contained reagent to assess the impurity. Standard Reference Material (SRM-1646a) of sediments was used in the recovery test by comparing the measured values with the certified values to ensure accuracy. Recovery of analysis varied from $83 \%$ to $108 \%$ depending upon the metal as shown in Table 1.

The organic carbon content (TOC) was determined in a $0.5 \mathrm{~g}$ of sample, avoiding contact with iron or steel, by wet oxidation and digestion by the Walkley-Black method. Oxidisable matter in the sediment was oxidised by $10.0 \mathrm{~mL}$ of $1 \mathrm{~N}$ potassium dichromate $\left(\mathrm{K}_{2} \mathrm{Cr}_{2} \mathrm{O}_{7}\right)$ solution. The reaction was assisted by the heat generated when two volumes of concentrated sulphuric acid $\left(\mathrm{H}_{2} \mathrm{SO}_{4}\right)$ was mixed with one volume of the dichromate. The remaining dichromate was titrated with ferrous sulphate $\left(\mathrm{Fe}_{2} \mathrm{SO}_{4} \cdot 7 \mathrm{H}_{2} \mathrm{O}\right)$. The titre is inversely related to the 
Table 1. Result of accuracy and precision analysis for Standard References Material (SRM), NBS 1646a estuarine sediments.

\begin{tabular}{ccccc}
\hline & Unit & Certified value & Analysed value & Recovery value (\%) \\
\hline $\mathrm{Li}$ & $\mathrm{ug}_{\mathrm{g}} \mathrm{g}^{-1}$ & 18 & 19.406 & 108 \\
$\mathrm{Al}$ & $\%$ & $2.297 \pm 0.018$ & 2.307 & 100 \\
$\mathrm{Cr}$ & ${\mathrm{ug} \cdot \mathrm{g}^{-1}}_{\mathrm{Mn}}$ & $40.9 \pm 1.9$ & 41.584 & 102 \\
$\mathrm{ug} \cdot \mathrm{g}^{-1}$ & $234.5 \pm 2.8$ & 194.059 & 83 \\
$\mathrm{Cu}$ & $\mathrm{ug} \cdot \mathrm{g}^{-1}$ & $10.01 \pm 0.34$ & 9.703 & 97 \\
$\mathrm{Cd}$ & $\mathrm{ug} \cdot \mathrm{g}^{-1}$ & $48.9 \pm 1.6$ & 48.515 & 99 \\
$\mathrm{~Pb}$ & $\mathrm{ug} \cdot \mathrm{g}^{-1}$ & $0.148 \pm 0.007$ & 0.139 & 94 \\
\hline
\end{tabular}

amount of carbon present in the sediment sample.

For the grain size analysis, sediment samples were oven dried $\left(105^{\circ} \mathrm{C}\right.$ for 24 hours) and about $200 \mathrm{~g}$ of sample was passed through 14 different mesh size sieves arranged consecutively downward from $4000 \mu \mathrm{m}$ to $<63 \mu \mathrm{m}$. For the fine fraction $(<63 \mu \mathrm{m})$, about $2 \mathrm{~g}$ of sample was diluted with distilled water and $10 \%$ of Calgon solution $\left(\mathrm{Na}_{6} \mathrm{P}_{6} \mathrm{O}_{18}\right)$ was added to disperse bonded particles in sediments. The grain size sediments of sediments were analysed using laser Particle Size Analyzer (PSA). Statistical analysis was carried out using SPSS software. Geographical Information System (GIS) was used to develop spatial variation maps. All data is reported as dry weight of sediments.

\section{Results}

\subsection{Physico-Chemical Parameters}

In situ measurements of water column (bottom layer) included several parameters such as $\mathrm{pH}$ which ranged from 6.91 to 8.15 , DO from 0.13 to $4.92 \mathrm{mg} / \mathrm{L}$ and salinity from $15.6 \%$ o to $30.81 \%$. Upstream sampling locations (P1 to P11) registered sand size (63 - $2000 \mu \mathrm{m})$ fraction only (Figure 2). The highest proportion of silt size (4 - $63 \mu \mathrm{m})$ was found at P23 (81.39\%) while for clay grain size $(<4 \mu \mathrm{m})$ is found in P21 (4.72\%). The average mean size of sediments of all sampling stations was $2.625 \phi$. Grain size generally decreased from the upstream towards the river mouth. Clay size fraction is less than $5 \%$.

TOC ranged from $5.33 \%$ at P10 to $0.36 \%$ at $\mathrm{P} 4$ with mean value of $2.16 \%$. TOC contents remained nearly unchanged at the upstream locations (P1 to P9; <1\%) but increased sharply at P10 and then remained consistent before gradually decreasing closer to the estuary. TOC (\%) in Pinang River is higher than the Langat River, Yangtze River and Pearl River [1] [16] indicating higher input under the tropical environment.

\subsection{Heavy Metals}

Concentrations of $\mathrm{Cd}, \mathrm{Cr}, \mathrm{Cu}, \mathrm{Mn}, \mathrm{Pb}$ and $\mathrm{Zn}$ in surficial sediments are given in Table 2 and spatial distribution maps are shown in Figure 3. Concentration of Cd varied between $0.07 \mu \mathrm{g} \cdot \mathrm{g}^{-1}$ and $1.52 \mu \mathrm{g} \cdot \mathrm{g}^{-1}$ with mean value of $0.53 \mu \mathrm{g} \cdot \mathrm{g}^{-1}$. The highest concentration of Cd was recorded at location P12 which is closer to jetty with intense boat activities. Concentration of $\mathrm{Cr}$ ranged from 18.8 to $122 \mu \mathrm{g} \cdot \mathrm{g}^{-1}$ with mean value of $58.4 \mu \mathrm{g} \cdot \mathrm{g}^{-1}$. The highest $\mathrm{Cr}$ concentration was measured at location P18 near the housing area. Both upstream and river mouth sampling locations showed higher $\mathrm{Cr}$ contents than the middle part of river. Concentration of $\mathrm{Cu}$ varied between $3.57 \mu \mathrm{g} \cdot \mathrm{g}^{-1}$ and $62.1 \mu \mathrm{g} \cdot \mathrm{g}^{-1}$ with mean value of $21.3 \mu \mathrm{g} \cdot \mathrm{g}^{-1}$ and showed a trend of increasing concentration from the upstream to downstream. The concentration of $\mathrm{Pb}$ varied between $8.42 \mu \mathrm{g} \cdot \mathrm{g}^{-1}$ and $83.5 \mu \mathrm{g} \cdot \mathrm{g}^{-1}$ with mean value of $25.9 \mu \mathrm{g} \cdot \mathrm{g}^{-1}$. Bothe upstream and downstream locations recorded lower $\mathrm{Pb}$ contents. Middle catchment locations (e.g. P17) close to the housing area registered higher contents. The concentrations of $\mathrm{Zn}$ varied from 46.6 to $317 \mu \mathrm{g} \cdot \mathrm{g}^{-1}$ with the mean value of $131 \mu \mathrm{g} \cdot \mathrm{g}^{-1}$. Mn concentration ranged from 39.8 to $375 \mu \mathrm{g} \cdot \mathrm{g}^{-1}$ 

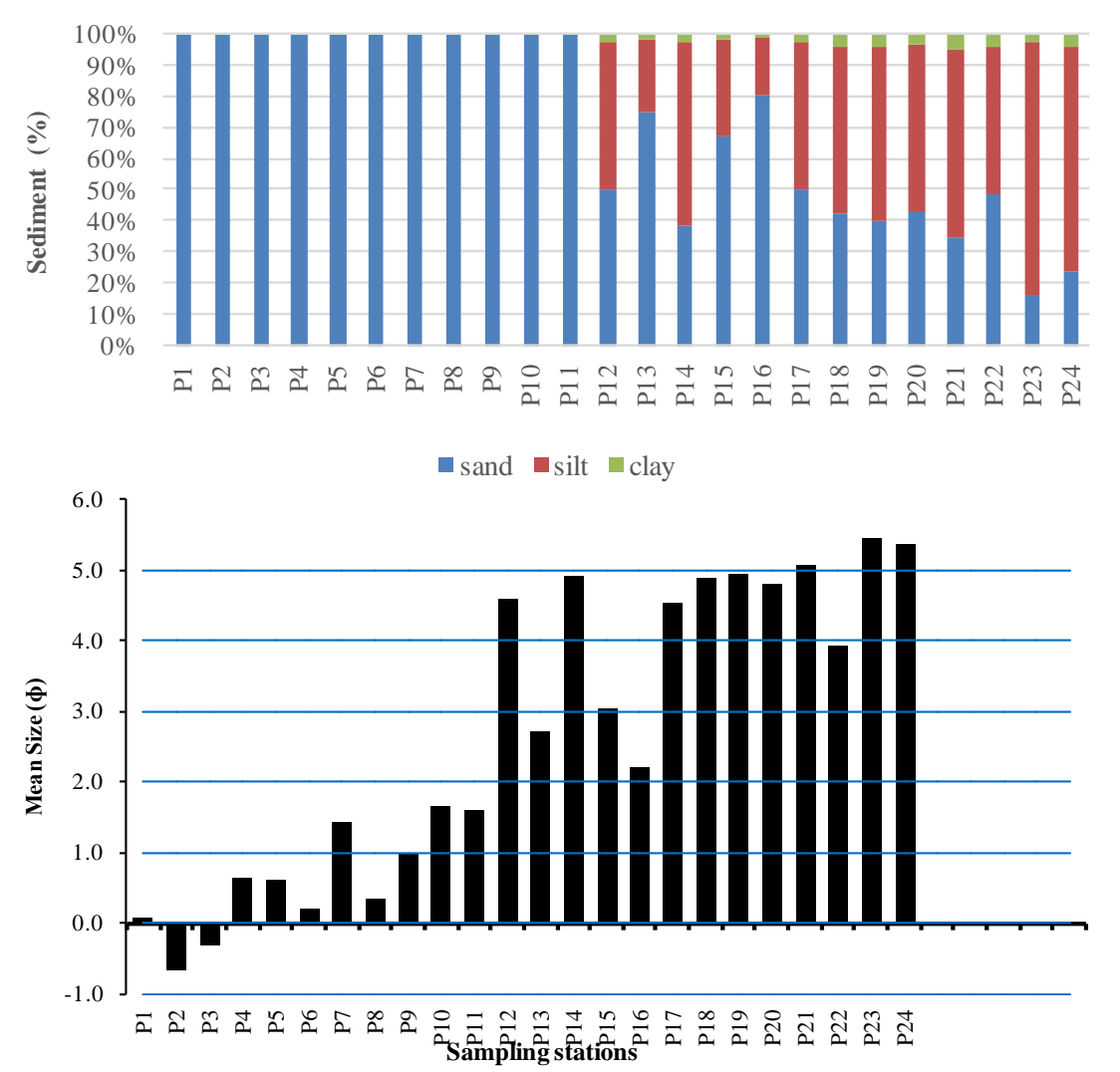

Figure 2. Percentage of sand, silt and clay size fractions of surface sediments and the change of mean size $(\phi)$ from upstream to the downstream of Pinang River.

with the mean value of $142 \mu \mathrm{g} \cdot \mathrm{g}^{-1}$. The highest Mn contents were recorded location, P24, which is close to the estuary. Mn contents showed high correlation with mean fine size sediments $(\mathrm{r}=0.83)$ and $\mathrm{Zn}, \mathrm{Cu}, \mathrm{Cr}$ and $\mathrm{Pb}$ showed medium correlation with $(r=0.64),(r=0.62),(r=0.41)$ and $(r=0.52)$ respectively. Cd showed a week correlation with mean sediments size $(r=0.37)$. Strong correlation between $\mathrm{Zn}$ and $\mathrm{Cu}(0.87)$ points to the same source which is probably anti-fouling paints contain about $15 \%$ - 30\% of metals [17] [18].

TOC showed a medium to strong correlations with studied metals, $\mathrm{Zn}(\mathrm{r}=0.71), \mathrm{Cu}(\mathrm{r}=0.70), \mathrm{Pb}(\mathrm{r}=0.63)$, Mn $(r=0.51)$, Cd $(r=0.45)$. TOC such as humic substances and fulvic acid provides absorption, ion exchange and forms complex (chelate compound) with metal re-deposition process [19] [20]. Synergic effect between fine sediments and TOC provide larger cation exchange capacities and higher surface to volume ratio for absorption process of metals ion in water column [1] [21].

\subsection{REE}

Concentration of REE and related statistical data in surficial sediments of Pinang River is shown in Table 3. Figure 4 shows spatial distribution maps of $\Sigma$ REE and selected REE concentration in surface sediments. The highest concentration among REEs was $982 \mu \mathrm{g} \cdot \mathrm{kg}^{-1}$ of Sm at the downstream location P22 and the lowest concentration of $0.1 \mu \mathrm{g} \cdot \mathrm{kg}^{-1}$ of Lu at the upstream location P2. The mean content of REE was $102 \mu \mathrm{g} \cdot \mathrm{kg}^{-1}$. In general, the downstream locations registered higher concentration of $\Sigma$ REE compared to the upstream locations. The sum of light REE ( $\Sigma$ LREE; La-Eu) contents of sediments was measured to be $16069.3 \mu \mathrm{g} \cdot \mathrm{kg}^{-1}$ with the mean value of $669.6 \mu \mathrm{g} \cdot \mathrm{kg}^{-1}$. The sum of heavy REEs ( $\Sigma$ HREE; Gd-Lu) contents was measured to be 898.0 $\mu \mathrm{g} \cdot \mathrm{kg}^{-1}$ with the mean value of $37.4 \mu \mathrm{g} \cdot \mathrm{kg}^{-1}$. The highest concentration of $\Sigma$ HREE was located at P19 (138.3 $\mu \mathrm{g} \cdot \mathrm{kg}^{-1}$ ) while for the lowest concentration was located P5 with $6.8 \mu \mathrm{g} \cdot \mathrm{kg}^{-1}$. REEs contents showed positive correlations (0.42 to 0.83 ) with mean grain size of sediments (except Sc, $r=-0.66$ ).

Both grain size and TOC contents of sediments showed a positive correlation with $\Sigma$ REE, $r=0.82$ and $r=$ 0.70 , respectively, and various metals (e.g. Zn) suggesting important controlling factors of metal distributions 
Table 2. Concentration of heavy metals ( $\mu \mathrm{g} \cdot \mathrm{g}^{-1}$ dry weight) in surficial sediments in Pinang River, Penang, Malaysia.

\begin{tabular}{ccccccc}
\hline & Cd & Cr & Cu & Mn & Pb & $\mathrm{Zn}$ \\
\hline P1 & 0.34 & 68.0 & 5.23 & 44.8 & 11.1 & 68.0 \\
P2 & 0.49 & 65.0 & 6.89 & 76.6 & 11.2 & 90.6 \\
P3 & 0.50 & 77.1 & 12.6 & 79.8 & 26.4 & 104 \\
P4 & 0.40 & 33.9 & 4.88 & 39.8 & 8.42 & 77.7 \\
P5 & 0.23 & 60.5 & 15.7 & 75.6 & 10.5 & 50.6 \\
P6 & 0.38 & 82.7 & 7.78 & 103 & 16.9 & 118 \\
P7 & 0.30 & 22.6 & 5.99 & 99.2 & 21.4 & 100 \\
P8 & 0.30 & 24.3 & 26.1 & 50.3 & 13.0 & 65.0 \\
P9 & 0.66 & 20.9 & 3.98 & 45.4 & 12.5 & 59.6 \\
P10 & 0.30 & 29.8 & 3.57 & 54.6 & 13.8 & 46.6 \\
P11 & 0.07 & 18.8 & 8.70 & 83.9 & 17.4 & 71.1 \\
P12 & 1.51 & 49.9 & 62.1 & 184 & 75.1 & 317 \\
P13 & 1.11 & 48.3 & 22.2 & 135 & 23.7 & 109 \\
P14 & 0.63 & 89.5 & 37.5 & 195 & 42.9 & 194 \\
P15 & 0.25 & 25.9 & 7.68 & 126 & 19.1 & 67.9 \\
P16 & 0.48 & 48.8 & 27.8 & 172 & 33.9 & 190 \\
P17 & 0.47 & 92.3 & 44.6 & 194 & 83.5 & 252 \\
P18 & 0.71 & 122 & 39.5 & 250 & 35.7 & 227 \\
P19 & 0.34 & 70.3 & 40.1 & 249 & 34.2 & 242 \\
P20 & 1.14 & 73.6 & 41.9 & 211 & 37.5 & 219 \\
P21 & 0.47 & 77.7 & 21.1 & 301 & 24.2 & 153 \\
P22 & 0.77 & 60.9 & 43.9 & 108 & 16.9 & 115 \\
P23 & 0.46 & 42.5 & 8.00 & 152 & 11.7 & 91.9 \\
P24 & 0.34 & 95.7 & 14.6 & 375 & 21.4 & 106 \\
\hline Average & 0.53 & 58.4 & 21.3 & 142 & 25.9 & 131 \\
Mev. & 0.33 & 27.8 & 16.9 & 88.8 & 19.1 & 75.2 \\
Pin & 0.07 & 18.8 & 3.57 & 39.8 & 8.42 & 46.6 \\
P19. & 1.51 & 122 & 62.1 & 375 & 83.5 & 317 \\
\hline
\end{tabular}

(Figure 5). This observation is in agreement with findings of river sediments of Brahmaputra River [22]. Coarser sediments tend to contain higher fraction of quartz, carbonate and feldspar and lower contents of mafic minerals [23]. Also, finer grain sizes has higher surface to volume ratio and clay minerals and, therefore, higher capacity of absorption of REE ions [24]. Downstream zone tends to have higher $\Sigma$ REE which may also due to high proportion of heavy minerals (e.g. zircon, monazite). Dissolved REE ions are removed from water column by sorption on to suspended particles and sediments coated with Fe and Mnoxyhydroxides [24].

Organic matter contains humic substances which provide high affinity for REE ion especially at near-neutral $\mathrm{pH}$ aquatic environments [24]. Compared to upper catchment, downstream zone has high percentage of TOC possibly due to continuous supply and accumulation of organic matter from terrestrial, urban runoff, untreated waste effluent.

\section{Discussion}

Texturally river sediments are classified as silt-sand and the sand size $(>2000 \mu \mathrm{m})$ fraction decreases towards 


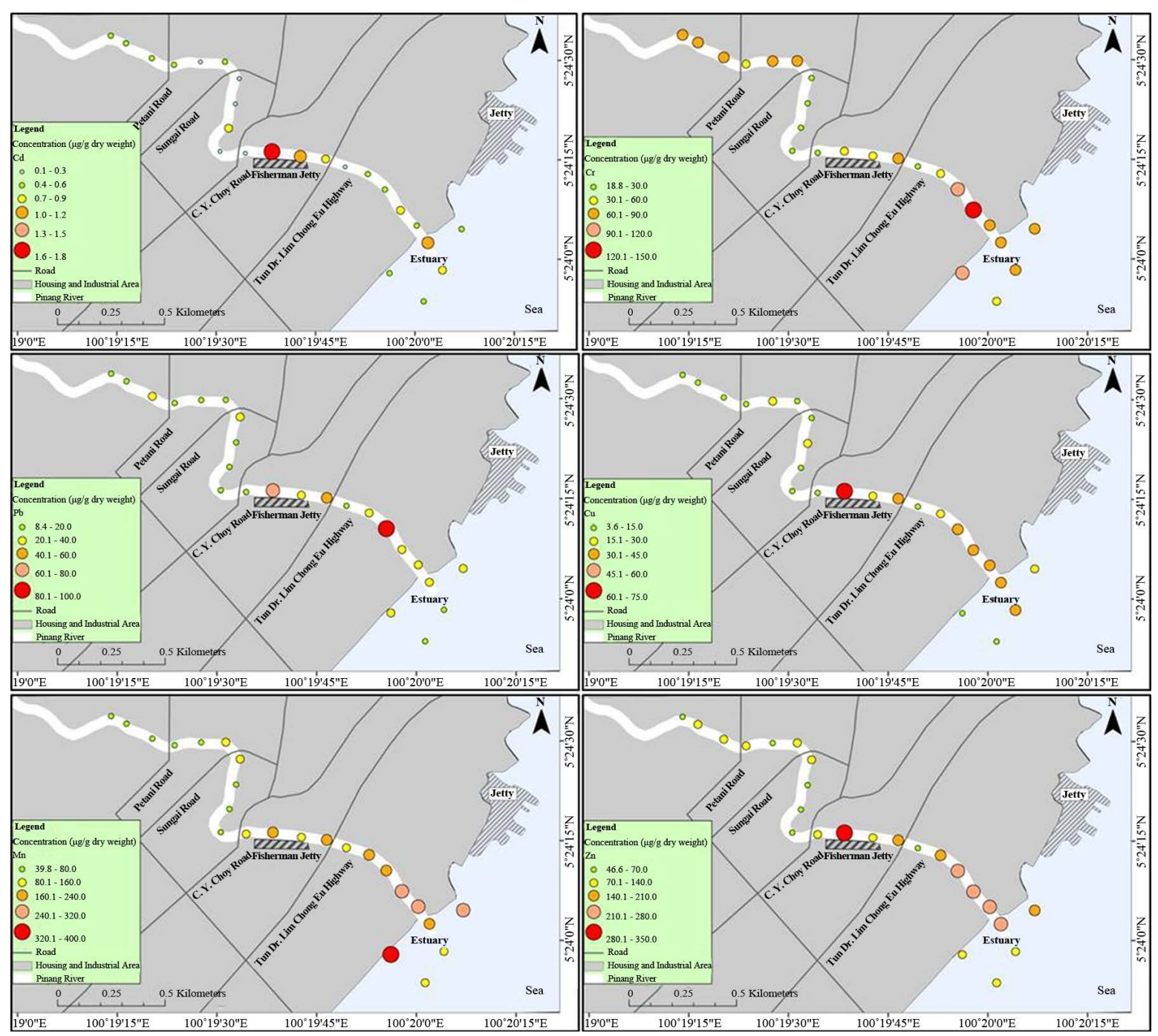

Figure 3. Spatial distribution maps of $\mathrm{Cd}, \mathrm{Cr}, \mathrm{Cu}, \mathrm{Pb}, \mathrm{Zn}$ and $\mathrm{Mn}$ contents in Penang River sediments. Midstream and downstream sampling locations generally registered higher levels.

river mouth. Upstream locations tend to have coarser grain size sediments due the removal of fine particles and deposition towards downstream locations deepening upon hydraulic energy and gradient. Tropical rain events are intense and significantly remove fine sediments to the sea.

Mn concentration increased gradually towards the river mouth. Downstream zone contains higher fraction of fine sediments and potentially provides larger binding sites for dissolved Mn ions in water column [20]. Moreover, downstream river water registered higher DO (up to $4.39 \mathrm{mg} / \mathrm{L}$ ) and pH (up to 8.15) that leads to precipitation of dissolved $\mathrm{Mn}^{2+}$ on surficial sediments under oxide environment.

Highest concentrations of $\mathrm{Cu}$ and $\mathrm{Cd}$ were determined at location P12 closer to the jetty. The input is most likely due to the fishing boat activities such as fish delivering, leakage of petrol and lubricant as well as antifouling paint residue [17] [25]. Besides, effluents from industrial activities such as metal plating and vehicle waste, and fuel leakage might cause addition of metals including $\mathrm{Cu}$ [26]. The highest content of $\mathrm{Pb}$ was found at location P17 which is closer to the industrial area (i.e. cable, paint and battery) and possibly the source of elevated levels of metals. An average $\mathrm{Zn}$ concentration of $130.6 \mu \mathrm{g} \cdot \mathrm{g}^{-1}$ is 2.5 times above the $52 \mu \mathrm{g} \cdot \mathrm{g}^{-1} \mathrm{value}$ [27] of upper continental crust. Housing area at downstream zone was observed and suggested that wastewater such as shampoo and detergent [28] discharged from urban activities might be the factor of Zn inputs in sediments. About 2 - 7 fold higher concentration of $\mathrm{Zn}$ was observed in the study area compared to Terengganu River, Port Klang and Kelantan River in Malaysia. 
Table 3. Concentration of REEs $\left(\mu \mathrm{g} \cdot \mathrm{kg}^{-1}\right.$ ) and characteristic parameter in surficial distribution of $\mathrm{Cu}$ concentration in the surficial sediments of Pinang River.

\begin{tabular}{|c|c|c|c|c|c|c|c|c|c|c|c|c|c|c|c|c|}
\hline & Sc & $\mathrm{Y}$ & $\mathrm{La}$ & Ce & Pr & $\mathrm{Nd}$ & $\mathrm{Sm}$ & $\mathrm{Eu}$ & Gd & $\mathrm{Tb}$ & Dy & Ho & $\mathrm{Er}$ & $\mathrm{Tm}$ & $\mathrm{Yb}$ & $\mathrm{Lu}$ \\
\hline P1 & 963 & 9.29 & 39.1 & 108 & 3.27 & 7.75 & 5.57 & 1.13 & 2.36 & 0.77 & 2.09 & 0.70 & 1.40 & 0.25 & 1.60 & 0.30 \\
\hline P2 & 921 & 11.2 & 40.1 & 188 & 4.46 & 10.9 & 6.51 & 1.78 & 3.24 & 0.62 & 3.60 & 0.76 & 1.95 & 0.22 & 1.14 & 0.13 \\
\hline P3 & 953 & 10.1 & 46.1 & 113 & 3.84 & 13.5 & 3.89 & 2.35 & 2.43 & 0.58 & 2.37 & 0.66 & 1.47 & 0.55 & 1.82 & 0.37 \\
\hline P4 & 850 & 4.72 & 21.5 & 74.6 & 2.98 & 4.96 & 1.45 & 1.39 & 1.88 & 0.15 & 1.19 & 0.71 & 1.23 & 0.28 & 0.93 & 0.41 \\
\hline P5 & 827 & 6.46 & 32.0 & 76.4 & 4.55 & 9.04 & 4.79 & 1.75 & 1.48 & 0.74 & 0.73 & 0.64 & 1.96 & 0.16 & 0.69 & 0.37 \\
\hline P6 & 969 & 26.2 & 80.7 & 151 & 8.28 & 23.1 & 5.01 & 0.89 & 4.90 & 0.73 & 3.10 & 0.99 & 3.71 & 0.65 & 1.98 & 0.67 \\
\hline P7 & 865 & 19.0 & 85.5 & 153 & 9.18 & 22.5 & 6.47 & 1.78 & 4.99 & 1.50 & 5.83 & 0.83 & 2.59 & 0.49 & 1.53 & 0.47 \\
\hline P8 & 981 & 20.9 & 60.5 & 122 & 6.87 & 18.3 & 5.89 & 2.34 & 3.97 & 0.72 & 4.23 & 0.79 & 2.48 & 0.82 & 2.26 & 0.53 \\
\hline P9 & 951 & 21.7 & 64.2 & 129 & 8.02 & 21.2 & 4.44 & 2.10 & 3.56 & 0.96 & 3.06 & 1.48 & 3.00 & 0.53 & 2.01 & 0.85 \\
\hline P10 & 974 & 18.2 & 60.2 & 119 & 9.11 & 22.6 & 4.78 & 1.49 & 3.85 & 0.70 & 3.47 & 0.77 & 2.90 & 0.87 & 2.23 & 0.37 \\
\hline P11 & 948 & 23.9 & 70.8 & 142 & 8.85 & 22.0 & 5.37 & 1.38 & 4.53 & 1.32 & 4.20 & 1.36 & 2.71 & 0.40 & 2.92 & 0.51 \\
\hline P12 & 759 & 74.8 & 355 & 662 & 38.7 & 137 & 18.4 & 3.00 & 16.0 & 3.94 & 11.8 & 3.20 & 10.3 & 1.75 & 5.49 & 1.47 \\
\hline P13 & 890 & 38.8 & 152 & 266 & 14.3 & 47.7 & 8.21 & 1.48 & 6.87 & 1.73 & 7.52 & 1.63 & 4.00 & 0.74 & 3.06 & 0.98 \\
\hline P14 & 744 & 74.0 & 234 & 721 & 31.2 & 63.9 & 22.5 & 2.69 & 15.0 & 2.66 & 10.7 & 2.55 & 7.13 & 2.31 & 7.25 & 1.26 \\
\hline P15 & 862 & 42.6 & 169 & 308 & 14.9 & 42.6 & 8.42 & 2.41 & 7.64 & 2.16 & 7.13 & 1.92 & 5.27 & 0.38 & 4.72 & 1.09 \\
\hline P16 & 834 & 89.0 & 262 & 520 & 31.5 & 86.4 & 17.5 & 3.25 & 18.3 & 4.48 & 15.7 & 4.10 & 10.8 & 1.59 & 6.11 & 1.70 \\
\hline P17 & 797 & 127 & 474 & 823 & 44.0 & 132 & 29.2 & 4.13 & 20.8 & 3.36 & 18.8 & 4.38 & 10.6 & 2.14 & 13.0 & 1.93 \\
\hline P18 & 788 & 138 & 445 & 914 & 49.1 & 159 & 21.0 & 3.99 & 23.9 & 6.29 & 25.2 & 6.00 & 17.2 & 2.06 & 13.2 & 2.58 \\
\hline P19 & 738 & 120 & 451 & 816 & 48.4 & 136 & 22.3 & 3.08 & 23.0 & 4.13 & 15.7 & 4.32 & 10.5 & 2.30 & 76.9 & 1.46 \\
\hline P20 & 748 & 121 & 401 & 827 & 42.5 & 142 & 27.4 & 3.94 & 17.4 & 5.78 & 21.1 & 4.26 & 9.8 & 1.71 & 9.8 & 1.97 \\
\hline P21 & 772 & 79.8 & 424 & 672 & 36.2 & 98.7 & 18.6 & 3.84 & 16.0 & 2.86 & 13.2 & 3.20 & 8.18 & 1.25 & 5.73 & 1.56 \\
\hline P22 & 982 & 16.3 & 75.5 & 112 & 7.00 & 21.3 & 5.25 & 2.42 & 4.89 & 1.13 & 2.37 & 0.99 & 1.76 & 0.34 & 2.45 & 0.71 \\
\hline P23 & 947 & 31.7 & 170 & 285 & 16.9 & 48.3 & 9.4 & 1.53 & 5.90 & 1.25 & 5.25 & 1.21 & 2.33 & 0.53 & 3.63 & 0.78 \\
\hline P24 & 788 & 84.0 & 428 & 894 & 39.3 & 112 & 23.9 & 3.51 & 17.1 & 4.26 & 11.6 & 3.87 & 9.12 & 1.82 & 12.8 & 1.45 \\
\hline Mean & 869 & 50.4 & 193 & 383 & 20.1 & 58.5 & 11.9 & 2.40 & 9.6 & 2.20 & 8.34 & 2.14 & 5.51 & 1.00 & 7.64 & 1.00 \\
\hline Std & 87.3 & 43.6 & 165 & 313 & 16.6 & 52.0 & 8.68 & 0.99 & 7.52 & 1.78 & 6.90 & 1.60 & 4.29 & 0.74 & 15.3 & 0.65 \\
\hline Min & 738 & 4.72 & 21.5 & 74.6 & 2.98 & 4.96 & 1.45 & 0.89 & 1.48 & 0.15 & 0.73 & 0.64 & 1.23 & 0.16 & 0.69 & 0.13 \\
\hline Max & 982 & 138 & 474 & 914 & 49.1 & 159 & 29.2 & 4.13 & 23.9 & 6.29 & 25.2 & 6.00 & 17.2 & 2.31 & 76.9 & 2.58 \\
\hline
\end{tabular}

\section{Continued}

\begin{tabular}{|c|c|c|c|c|c|c|c|c|c|c|c|}
\hline & ¿REEs & LREE & REE & LREE/HREE & Ce/La & $\mathbf{G d} / \mathbf{Y b}$ & $\mathbf{L a} / \mathbf{Y b}$ & La/Lu & La/Sm & $\mathrm{Ce} / \mathrm{Ce}^{*}$ & $\mathbf{E u} / \mathbf{E u}^{*}$ \\
\hline $\mathrm{P} 1$ & 175 & 165 & 9.47 & 17.5 & 1.08 & 1.22 & 16.9 & 13.3 & 4.39 & 1.97 & 0.95 \\
\hline $\mathrm{P} 2$ & 263 & 252 & 11.7 & 21.6 & 1.83 & 2.34 & 24.3 & 30.8 & 3.86 & 3.63 & 1.18 \\
\hline P3 & 193 & 183 & 10.3 & 17.8 & 0.96 & 1.11 & 17.6 & 13.0 & 7.43 & 2.32 & 2.32 \\
\hline $\mathrm{P} 4$ & 114 & 107 & 6.76 & 15.8 & 1.35 & 1.68 & 16.1 & 5.5 & 9.27 & 1.81 & 2.56 \\
\hline P5 & 135 & 129 & 6.76 & 19.0 & 0.93 & 1.77 & 32.2 & 8.9 & 4.19 & 1.12 & 1.99 \\
\hline P6 & 285 & 269 & 16.7 & 16.0 & 0.73 & 2.05 & 28.2 & 12.4 & 10.1 & 1.33 & 0.54 \\
\hline P7 & 297 & 279 & 18.2 & 15.3 & 0.70 & 2.69 & 38.6 & 18.8 & 8.27 & 1.52 & 0.95 \\
\hline P8 & 232 & 216 & 15.8 & 13.7 & 0.79 & 1.45 & 18.5 & 11.8 & 6.43 & 1.33 & 1.47 \\
\hline P9 & 245 & 229 & 15.5 & 14.8 & 0.78 & 1.46 & 22.1 & 7.82 & 9.06 & 1.28 & 1.60 \\
\hline P10 & 232 & 217 & 15.2 & 14.3 & 0.77 & 1.43 & 18.7 & 16.7 & 7.89 & 1.24 & 1.05 \\
\hline P11 & 269 & 251 & 18.0 & 14.0 & 0.78 & 1.28 & 16.8 & 14.5 & 8.28 & 0.65 & 0.85 \\
\hline P12 & 1268 & 1214 & 53.9 & 22.5 & 0.72 & 2.40 & 44.8 & 25.1 & 12.1 & 2.23 & 0.53 \\
\hline P13 & 516 & 490 & 26.5 & 18.5 & 0.68 & 1.86 & 34.4 & 16.1 & 11.6 & 0.93 & 0.60 \\
\hline P14 & 1123 & 1075 & 48.9 & 22.0 & 1.20 & 1.71 & 22.3 & 19.2 & 6.52 & 2.93 & 0.45 \\
\hline P15 & 576 & 545 & 30.3 & 18.0 & 0.71 & 1.34 & 24.7 & 16.1 & 12.6 & 1.01 & 0.91 \\
\hline P16 & 983 & 920 & 62.8 & 14.7 & 0.77 & 2.48 & 29.7 & 15.9 & 9.37 & 1.16 & 0.55 \\
\hline P17 & 1582 & 1507 & 75.1 & 20.1 & 0.68 & 1.33 & 25.3 & 25.4 & 10.2 & 1.29 & 0.51 \\
\hline P18 & 1688 & 1592 & 96.5 & 16.5 & 0.80 & 1.49 & 23.3 & 17.8 & 13.3 & 1.49 & 0.54 \\
\hline P19 & 1615 & 1477 & 138 & 10.7 & 0.70 & 0.25 & 4.06 & 32.1 & 12.7 & 1.41 & 0.41 \\
\hline P20 & 1515 & 1444 & 71.8 & 20.1 & 0.80 & 1.46 & 28.2 & 21.1 & 9.15 & 1.65 & 0.55 \\
\hline P21 & 1306 & 1254 & 52.1 & 24.1 & 0.62 & 2.31 & 51.3 & 28.1 & 14.3 & 2.96 & 0.68 \\
\hline P22 & 238 & 224 & 14.6 & 15.3 & 0.58 & 1.65 & 21.4 & 11.1 & 9.03 & 0.75 & 1.45 \\
\hline P23 & 552 & 531 & 20.9 & 25.4 & 0.65 & 1.34 & 32.4 & 22.6 & 11.3 & 0.83 & 0.62 \\
\hline P24 & 1564 & 1502 & 62.0 & 24.2 & 0.81 & 1.10 & 23.1 & 30.6 & 11.2 & 2.31 & 0.53 \\
\hline Mean & 707 & 670 & 37.4 & 18.0 & 0.85 & 1.63 & 25.6 & 18.1 & 9.27 & 1.63 & 0.99 \\
\hline Std & 582 & 551 & 33.5 & 3.84 & 0.28 & 0.55 & 10.0 & 7.50 & 2.87 & 0.76 & 0.61 \\
\hline Min & 114 & 107 & 6.76 & 10.7 & 0.58 & 0.25 & 4.06 & 5.45 & 3.86 & 0.65 & 0.41 \\
\hline Max & 1688 & 1592 & 138 & 25.4 & 1.83 & 2.69 & 51.3 & 32.1 & 14.3 & 3.63 & 2.56 \\
\hline
\end{tabular}



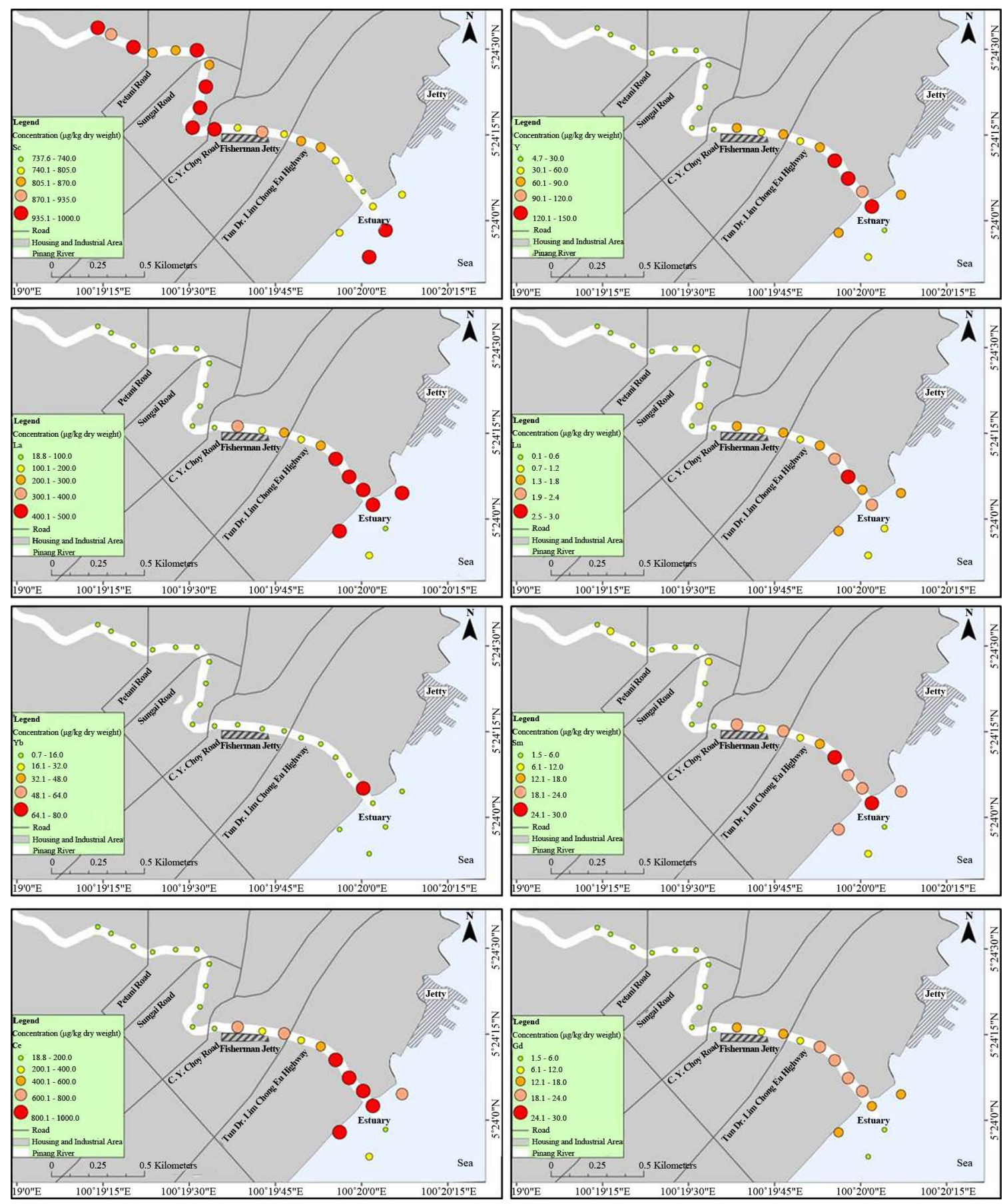

Figure 4. Spatial distribution of selected REE in surface sediments of Pinang River. Most REE showed higher concentration close to the river mouth with the exception of a few (e.g. Sc).

Heavy metal concentration changes showed more or less three distinct trends along the river flow path (Figure 6). $\mathrm{Zn}, \mathrm{Pb}, \mathrm{Cu}$ and $\mathrm{Cd}$ all registered lower concentrations in the upstream than the downstream locations. $\mathrm{Cr}$ concentration was higher at upstream and downstream locations but much lower in the middle catchment of the river. Mn concentration systematically increased along the river with the higher values close to the estuary pointing to precipitation and/or adsorption onto sediments.

The order of abundance of REEs in sediments was observed to be $\mathrm{Sc}>\mathrm{Ce}>\mathrm{La}>\mathrm{Nd}>\mathrm{Y}>\mathrm{Pr}>\mathrm{Sm}>\mathrm{Gd}>$ $\mathrm{Dy}>\mathrm{Yb}>\mathrm{Er}>\mathrm{Eu}>\mathrm{Tb}>\mathrm{Ho}>\mathrm{Tm}>\mathrm{Lu}$. The enrichment of LREE over HREE and nearly flat pattern of 


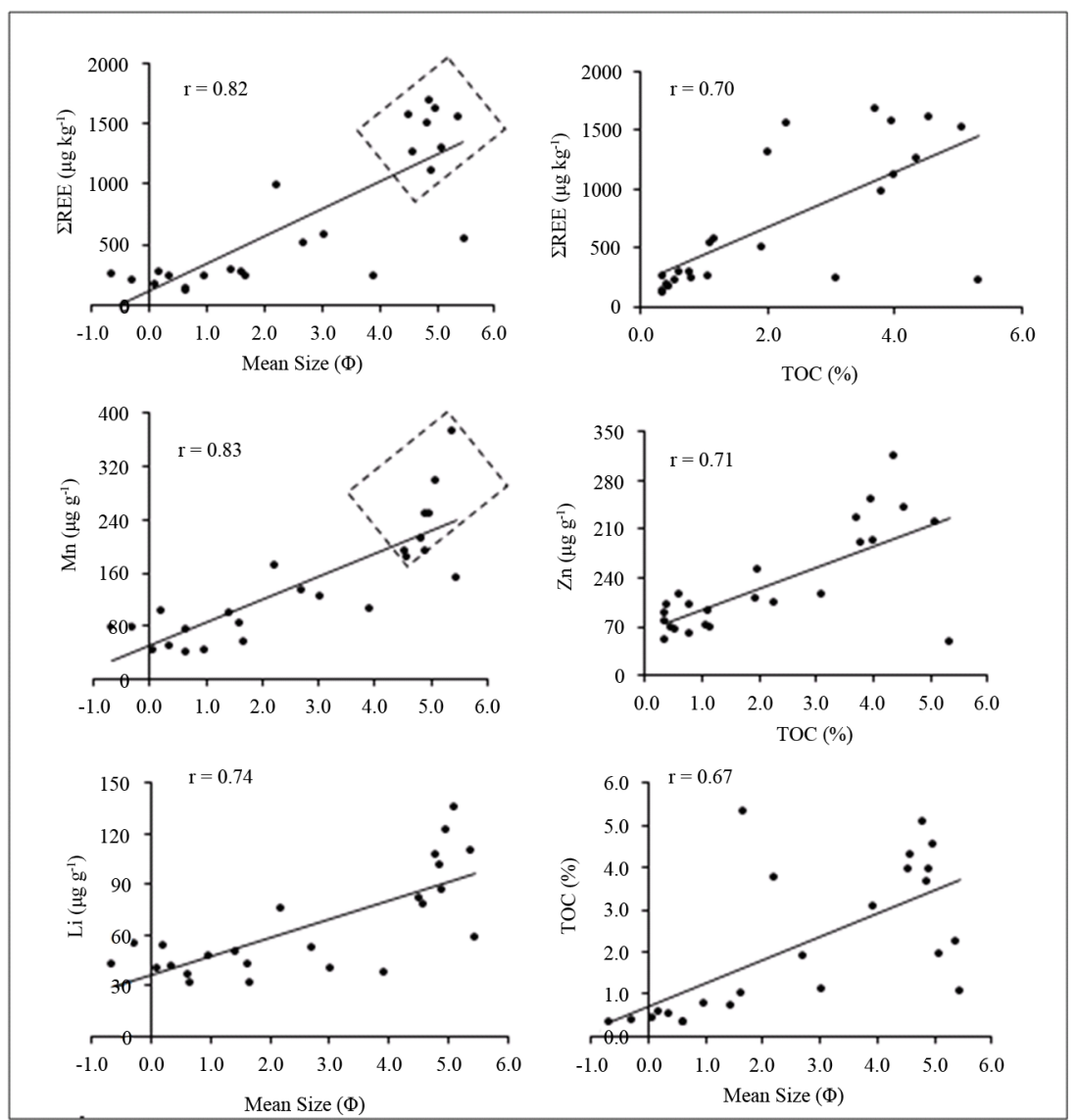

Figure 5. Plots of grain size and TOC against REEs, Mn and $\mathrm{Zn}$ in sediments of Pinang River. Rectangles with broken lines enclose samples with high concentration of REEs and Mn and fine grain size fraction at the downstream locations.

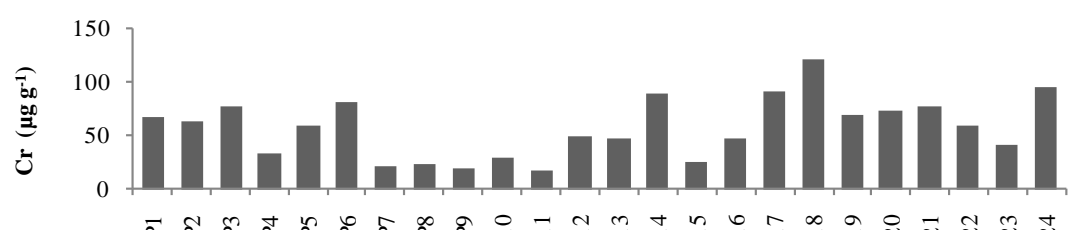

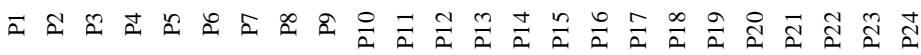

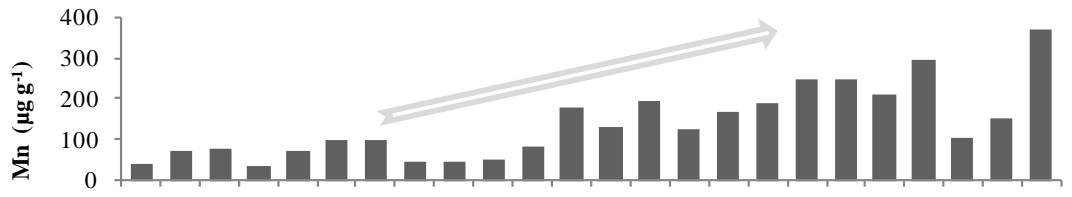

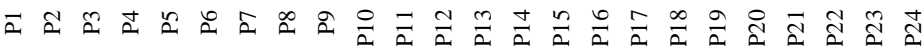

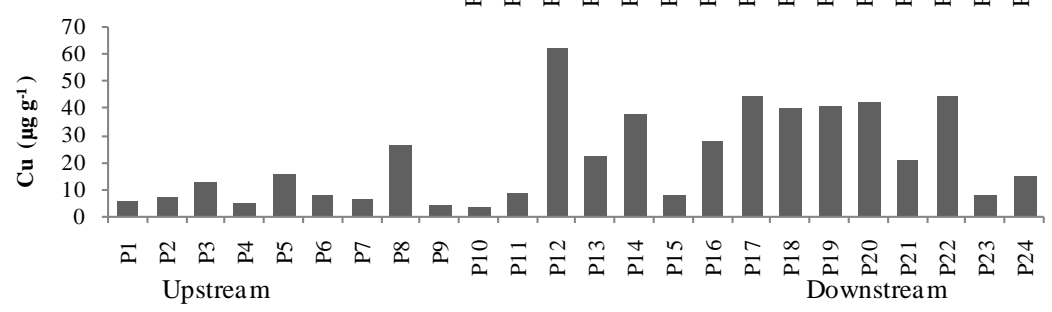

Figure 6. Graphs showing various trends in concentration changes along the Penang river from upstream to downstream. Note gradual increase of few metals and an abrupt change at location P12. 
HREE is shown in Figure 7 of Chondrite normalized concentrations. The various patterns of chondrite normalized REEs point to the origin and in situ processes of enrichment or depletion. Chondrite meteorite composition was used to normalize REEs as it represents the primordial earth and also considering the granitoids as the dominant at the study area. A similar pattern was reported in Terengganu River Basin [29] and marine sediments of the South China Sea [30]. Slightly positive Ce anomaly and negative Eu anomaly was also observed.

$\Sigma$ LREE is more abundant as compared to $\Sigma$ HREE with an average $\Sigma$ LREE/ $/$ HREE ratio of 18.0. Estuarine environment have higher content of carbonate that leads to the enrichment $\Sigma$ LREE in surficial sediments [32]. The mean value of $\Sigma$ REE (707.0 ug $\cdot \mathrm{kg}^{-1}$ ) in Pinang River sediments is observed to be lower than UCC [27] which suggested low contents of REE containing rare earth mineral inputs. Ratio of (La/Yb) N ranged from 4.06 to 51.3 with the mean value of 25.6. Higher $(\mathrm{La} / \mathrm{Yb}) \mathrm{N}$ ratio with Eu anomaly also suggests sediment source of granite. River sediments showed a slightly positive Ce anomaly, 1.63, mostly likely due to the change of soluble Ce (III) into insoluble Ce (IV) in water column under oxidizing conditions. In general, sediment Ce anomaly decreased towards estuary. Under the prevailing pH-redox conditions, the insoluble Eu (II) tends to form soluble $\mathrm{Eu}$ (III), hence change in Eu anomaly from upstream to the downstream.

A multivariate assessment of surface sediments contamination included determination of enrichment factor (EF), Index of Geoaccumulation $\left(I_{\text {geo }}\right)$ and Pollution Load Index (PLI). Assessments were calculated using upper continental crust (UCC) values of elements as background.

For Enrichment Factor (EF) calculation, Li was used a reference element to normalize the metal concentrations. Concentration of Li showed a positive correlation with mean sediment grain size and most of the metals measured. EF was used to estimate whether metal input is natural or anthropogenic An EF value of less than 2.0 is considered natural. The EF is calculated as presented by Buat-Menard and Chesselet [33]:

$$
\mathrm{EF}=\frac{\left(\frac{M}{\mathrm{Li}}\right) \text { Sample }}{\left(\frac{M}{\mathrm{Li}}\right) \text { Background }}
$$

where,

$\left(\frac{M}{\mathrm{Li}}\right)$ Sample is the ratio of concentration metal and $\mathrm{Li}$ of the sample.

$\left(\frac{M}{\mathrm{Li}}\right)$ Background is the ratio of concentration metal and $\mathrm{Al}$ of background.

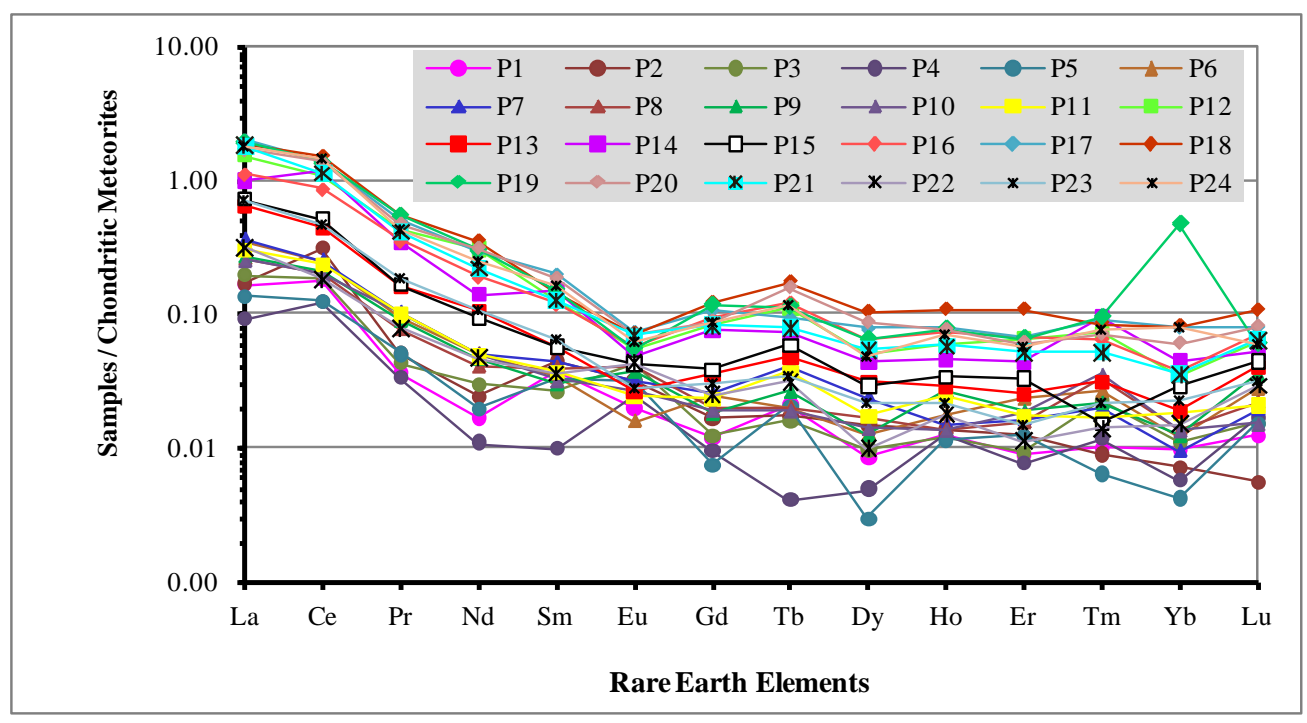

Figure 7. Chondrite-normalized REE patterns of the surface sediments of Pinang River. Chondrite values are after Anders and Grevesse [31]. 
EF value followed order $\mathrm{Cd}>\mathrm{Zn}>\mathrm{Cr}>\mathrm{Pb}>\mathrm{Cu}>\mathrm{Mn}$. The moderate anthropogenic of metal $\mathrm{Cd}$ at $\mathrm{P} 2$ (2.43), P4 (2.67), P9 (3.01), P12 (4.16), P13 (4.56), P20 (2.28), P22 (4.29) might relate to local point discharge. EF for REE was less than 2 and therefore, all sources of REE are natural. Anthropogenic enrichment of REE is mainly caused by ore mining activities and through observation the Pinang River catchments do not have mining activities.

Geo-accumulation Index $\left(I_{\text {geo }}\right)$ is used to assess the quality of sediments [34] and is calculated by the following formula:

$$
I_{\text {geo }}=\log _{2}\left[\frac{\mathrm{Cn}}{1.5 \mathrm{Bn}}\right]
$$

Where, $\mathrm{Cn}$ is concentrations of a heavy metal element in the sample, $\mathrm{Bn}$ is background value, 1.5 is the correction factor.

An $I_{g e o}$ value of $\geq 1$ is considered unpolluted to moderate level. Pollution level of $\operatorname{Cr}\left(I_{g e o}=2.1\right)$ showed moderately to strongly polluted and $I_{g e o} \mathrm{Cd}$ was found to be 1.54 . The calculated $I_{g e o}$ values followed the order of $\mathrm{Cr}>$ $\mathrm{Cd}>\mathrm{Zn}>\mathrm{Pb}>\mathrm{Cu}>\mathrm{Mn}$.

Pollution load index (PLI) gives better understanding for the level of contamination of heavy metals [35] in coastal and estuarine surface sediments.

PLI is calculated as:

$$
\begin{gathered}
\mathrm{CF}=\frac{(C) \text { Sample }}{(C) \text { Background }} \\
\sqrt[n]{\left(\mathrm{CF}_{\text {Metal }}\right)}
\end{gathered}
$$

where, CF is contamination factor which $(C)_{\text {sample }}$ is concentration of metal in sample, $(C)_{\text {background }}$ is background value of the metal. " $n$ " is the number of metals measured.

The PLI varied from 0.60 to 3.09 (average 1.44). A PLI value above 1 indicates contamination. Sampling station with PLI value above 1 are in the order of P12 > P17 > P18 > P20 > P14 > P19 > P21 > P16 > P22 > P13 > P24 > P23 were mostly found at the downstream of river. This might be caused by the higher anthropogenic input at downstream than the upstream and due to the accumulative build up in sediments (i.e. sink) of metals. Fishing activities were found at P12 and there are high possibilities of major sources of metals were derived from boat activities. Retention of metals in sediments is due to the multi factors including grain size, TOC and $\mathrm{pH}$-redox conditions and when conditions change metals can become mobile (i.e. source) in the aquatic ecosystem.

\section{Conclusions}

Among the elements measured in surface sediments of Penang River, $\mathrm{Cd}, \mathrm{Cr}, \mathrm{Zn}$ and $\mathrm{Pb}$ concentrations were found to be significantly elevated and, therefore, might pose a threat to the aquatic ecosystem. A multivariate assessment indicated moderately to highly polluted levels of metals which are in agreement with overall river quality previously classified as degraded but without reporting of the elemental data. Serious issues of pollution are related to the site near jetty which possibly serves as a point source for metal enrichment to the sediment. Sources of rare earth elements are natural and no significant environmental issue was observed owing to the low anthropogenic inputs (i.e. mining).

Most of the metals, TOC, fine grain size fraction and $\Sigma$ REE concentration showed a trend of increasing values from upstream towards the river mouth. It is most likely due to the hydraulic conditions caused by intense tropical rain events that remove and transport fine sediment particles from upper catchments (dominantly sand) to the downstream locations (silty sand texture).

Chondrite-normalized rare-earth elements (REE) patterns showed higher LREE as compared to HREE. Fine particles, TOC and high pH-redox conditions favor enrichment of metals close to the estuary as compared to the upstream river waters. Longer contact time of metal ions in the water column under low flow rate (downstream locations) retains metals on surface sediments resulting in elevated levels. Fine sediment size has higher ratio of surface area to volume than the coarser sediments and therefore, provides larger area of binding site. This work 
contributed by documenting the current levels of 22 elements so that any changes in future can be monitored and managed considering the Penang River catchment areas undergoing rapid urban development.

\section{Acknowledgements}

Authors would like to thank the Oceanography and Biodiversity Laboratory, School of Marine and Environmental Science and Institute of Oceanography and Environment for providing the facilities to carry out the research work. Thanks also to our friends for their help in sampling and continued support during the laboratory work. We appreciate valuable time of Mr Yuzwan bin Mohammad spent in preparing maps using GIS.

\section{References}

[1] Zhou, J., Ma, D., Pan, J., Nie, W. and Wu, K. (2008) Application of Multivariate Statistical Approach to Identify Heavy Metal Sources in Sediment and Waters: A Case Study in Yangzhong, China. Environmental Geology, 54, 373380. http://dx.doi.org/10.1007/s00254-007-0824-5

[2] He, Z., Song, J., Zhang, N., Zhang, P. and Xu, Y. (2009) Variation Characteristics and Ecological Risk of Heavy Metals in the South Yellow Sea Surface Sediments. Environment Monitor Assessment, 157, 515-528. http://dx.doi.org/10.1007/s10661-008-0552-7

[3] Mulligan, C., Fukue, M. and Sato, Y. (2010) Sediment Contamination and Sustainable Remediation. CRC Press, London.

[4] Dhanakumar, S., Murthy, K.R., Solaraj, G. and Mohanraj, R. (2013) Heavy-Metal Fractionation in Surface Sediments of the Cauvery River Estuarine Region, Southeastern Coast of India. Archives of Environmental Contamination and Toxicology, 65, 14-23. http://dx.doi.org/10.1007/s00244-013-9886-4

[5] Lin, C., He, M., Zhou, Y., Guo, W. and Yang, Z. (2008) Distribution and Contamination Assessment of Heavy Metals in Sediment of the Second Songhua River, China. Environment Monitor Assessment, 137, 329-342. http://dx.doi.org/10.1007/s10661-007-9768-1

[6] Ochieng, E.Z., Lalah, J.O. and Wandiga, S.O. (2007) Analysis of Heavy Metals in Water and Surface Sediment in Five Rift Valley Lakes in Kenya for Assessment of Recent Increase in Anthropogenic Activities. Bulletin of Environmental Contamination and Toxicology, 79, 570-576. http://dx.doi.org/10.1007/s00128-007-9286-4

[7] Ong, M.C., Menier, D., Shazili, N. and Kamaruzzaman, B.Y. (2013) Geochemical Characteristics of Heavy Metals Concentration in Sediments of Quiberon Bay Waters, South Brittany, France. Oriental Journal of Chemistry, 29, 39-45. http://dx.doi.org/10.13005/ojc/290106

[8] The Geological Society (2011) Rare Earth Elements: A Briefing Note by the Geological Society of London. http://www.geolsoc.org.uk

[9] Burton, G.A. (2002) Sediment Quality Criteria in Use around the World. Limnology, 3, 65-75. http://dx.doi.org/10.1007/s102010200008

[10] Françaa, S., Vinagrea, C., Caçadora, I. and Cabrala, H.N. (2005) Heavy Metal Concentrations in Sediment, Benthic Invertebrates and Fish in Three Salt Marsh Areas Subjected to Different Pollution Loads in the Tagus Estuary (Portugal). Marine Pollution Bulletin, 50, 998-1003. http://dx.doi.org/10.1016/j.marpolbul.2005.06.040

[11] Mei, J., Li, Z., Sun, L., Gui, H. and Wang, X. (2011) Assessment of Heavy Metals in the Urban River Sediments in Suzhou City, Northern Anhui Province, China. Procedia Environmental Sciences, 10, 2547-2553. http://dx.doi.org/10.1016/j.proenv.2011.09.396

[12] Drainage and Irrigation Department (2000) Quality Monitoring Report for Sungai Pinang River Basin. Drainage and Irrigation Department, Penang, Malaysia

[13] Usali, N., and Ismail, M.H. (2010) Use of Remote Sensing and GIS in Monitoring Water Quality. Journal of Sustainable Development, 3. http://dx.doi.org/10.5539/jsd.v3n3p228

[14] Maznah, W.O. and Mansor, M. (2002) Aquatic Pollution Assessment Based on Attached Diatom Communities in the Pinang River Basin, Malaysia. Hydrobiologia, 487, 229-241. http://dx.doi.org/10.1023/A:1022942200740

[15] Saad, F.N., Rahman, N.N., Kadir, M.O. and Omar, F.M. (2008) Identification of Pollution Sources within the Sungai Pinang River Basin. Universiti Sains Malaysia, 478-485.

[16] Liu, B., Hu, K., Jiang, Z., Yang, J., Luo, X. and Liu, A. (2011) Distribution and Enrichment of Heavy Metals in a Sediment Core from the Pearl River Estuary. Environment Earth Science, 62, 265-275. http://dx.doi.org/10.1007/s12665-010-0520-8

[17] Thomas, K.V., McHugh, M. and Waldock, M. (2002) Antifouling Paint Booster Biocides in UK Coastal Waters: Inputs, Occurrence, and Environmental Fate. Science of Total Environment, 293,117-127. 
http://dx.doi.org/10.1016/S0048-9697(01)01153-6

[18] Gibert, O., Martínez-Lladó, X., Martí, V., Díez, S., Romo, J., Bayona, J.M. and Pablo, J. (2009) Changes of Heavy Metal and PCB Contents in Surficial Sediments of the Barcelona Harbour after the Opening of a New Entrance. Water, Air, and Soil Pollution, 204, 271-284. http://dx.doi.org/10.1007/s11270-009-0044-6

[19] Wang, G.-P., Yu, X.-F., Wang, J., Zhao, H.-M., Bao, K.-S. and Lu, X.-G. (2011) Dominants and Accumulation of Rare Earth Elements in Sediments Derived from Riparian and Depressional Marshes. Environmental Earth Sciences, 62, 207-216. http://dx.doi.org/10.1007/s12665-010-0515-5

[20] Sany, S.B., Salleh, A., Sulaiman, A.H., A. Sasekumar, M.R. and Tehrani, G.M. (2013) Heavy Metal Contamination in Water and Sediment of the Port Klang Coastal Area, Selangor, Malaysia. Environmental Earth Sciences, 69, 20132025. http://dx.doi.org/10.1007/s12665-012-2038-8

[21] Erdem, E., Karapinar, N. and Donat, R. (2004) The Removal of Heavy Metal Cations by Natural Zeolites. Journal of Colloid and Interface Science, 280, 309-314. http://dx.doi.org/10.1016/j.jcis.2004.08.028

[22] Li, C., Kang, S., Zhang, Q. and Wang, F. (2009) Rare Earth Elements in the Surface Sediments of the Yarlung Tsangbo (Upper Brahmaputra River) Sediments, Southern Tibetan Plateau. Quaternary International, 208, 151-157. http://dx.doi.org/10.1016/j.quaint.2009.05.003

[23] Lee, S., Kim, J.K., Yang, D.Y. and Kim, J.Y. (2008) Rare Earth Element Geochemistry and Nd Isotope Composition of Stream Sediments, South Han River Drainage Basin, Korea. Quaternary International, 176-177, 121-134.

[24] Morgan, B., Rate, A.W., Burton, E.D. and Smirk, M.N. (2012) Enrichment and Fractionation of Rare Earth Elements in FeS- and Organic-Rich Estuarine Sediments Receiving Drainage from Acid-Sulfate Soils. Chemical Geology, 308309, 60-73. http://dx.doi.org/10.1016/j.chemgeo.2012.03.012

[25] Dar, M.A. (2012) Distribution Patterns of Some Heavy Metals in the Surface Sediment Fractions at Northern Safaga Bay, Red Sea, Egypt. Arabian Journal of Geosciences, 7, 1-13.

[26] Fu, J., Zhao, C., Luo, Y., Liu, C., Kyzas, G.Z., Luo, Y., Zhao, D., An, S. and Zhu, H. (2014) Heavy Metals in Surface Sediments of the Jialu River, China: Their Relations to Environmental Factors. Journal of Hazardous Materials, 270, 102-109. http://dx.doi.org/10.1016/j.jhazmat.2014.01.044

[27] Wedepohl, K.H. (1995) The Composition of the Continental Crust. Geochemicaet Cosmochimica Acta, 59, $1217-1239$. http://dx.doi.org/10.1016/0016-7037(95)00038-2

[28] Cuong, D.T., Karuppiah, S. and Obbard, J.P. (2008) Distribution of Heavy Metals in the Dissolved and Suspended Phase of the Sea Surface Microlayer, Seawater Column and in the Sediments of Singapore's Coastal Environment. Environmental Monitoring Assessment, 138, 255-272. http://dx.doi.org/10.1007/s10661-007-9795-y

[29] Sultan, K. and Shazili, N.M. (209) Rare Earth Elements in Tropical Surface Water, Soil and Sediments of the Terengganu River Basin, Malaysia. Journal of Rare Earths, 27, 1072-1078. http://dx.doi.org/10.1016/S1002-0721(08)60391-9

[30] Khadijeh, R.E., Elias, S.B., Wood, A.K. and Reza, A.M. (2009) Rare Earth Elements Distribution in Marine Sediments of Malaysia Coasts. Journal of Rare Earths, 27, 1066-1076. http://dx.doi.org/10.1016/S1002-0721(08)60390-7

[31] Anders, E. and Grevesse, N. (1989) Abundances of the Elements: Meteoritic and Solar. Geochemicaet Cosmochimica Acta, 53, 197-214. http://dx.doi.org/10.1016/0016-7037(89)90286-X

[32] Kanazawa, Y. and Kamitani, M. (2006) Rare Earth Minerals and Resources in the World. Journal of Alloys and Compounds, 408-412, 1339-1343. http://dx.doi.org/10.1016/j.jallcom.2005.04.033

[33] Buat-Menard, P. and Chesselet, R. (1979) Variable Influence of Atmospheric Flux on the Trace Metal Chemistry of Oceanic Suspended Matter. Earth and Planetary Science Letters, 42, 398-411. http://dx.doi.org/10.1016/0012-821X(79)90049-9

[34] Nobi, E., Dilipan, E., Thangaradjou, T., Sivakumar, K. and Kannan, L. (2010) Geochemical and Geo-Statistical Assessment of Heavy Metal Concentration in the Sediments of Different Coastal Ecosystems of Andaman Islands, India. Estuarine, Coastal and Shelf Science, 87, 253-264. http://dx.doi.org/10.1016/j.ecss.2009.12.019

[35] Tomlinson, D.L., Wilson, J.G., Harris, C.R. and Jeffrey, D.W. (1980) Problems in the Assessment of Heavy-Metal Levels in Estuaries and the Formation of a Pollution Index. Helgoländer Meeresuntersuchungen, 33, 566-575. http://dx.doi.org/10.1007/BF02414780 